\title{
The enhancing antibiofilm activity of curcumin on Streptococcus mutans strains from severe early childhood caries
}

\author{
Bingchun Li ${ }^{1,2}$, Ting Pan ${ }^{1,2}$, Huancai Lin ${ }^{1,2^{*}}$ and Yan Zhou ${ }^{1,2^{*}}$
}

\begin{abstract}
Background: Streptococcus mutans (S. mutans) is one of the main cariogenic bacteria for caries. It was found that the clinical strains of $S$. mutans isolated from caries active population have stronger cariogenic ability than the isolates from caries-free (CF) people. Previous studies have found that curcumin can inhibit biofilm formation of $S$. mutans UA159. The objective of this study is to explore the antibiofilm effect of curcumin on the clinical isolates of S. mutans from severe early childhood caries(SECC).
\end{abstract}

Results: The isolates from SECC group had more biomass than CF group ( $t=4.296, P<0.001)$. The acidogenicity and aciduricity of the strains from two groups showed no significant difference. After treatment with curcumin, the viability of biofilm was reduced to $61.865 \% \pm 7.108 \%$ in SECC and to $84.059 \% \pm 10.227 \%$ in CF group at $24 \mathrm{~h}$ ( $P<$ 0.05). The net reduction of live bacteria and total bacteria in the SECC group was significantly higher than that of the CF group (live bacteria $\mathrm{t}=3.305, P=0.016$; total bacteria $\mathrm{t}=2.378, P=0.045$ ) at $5 \mathrm{~min}$. For $24 \mathrm{~h}$, the net reduction of live bacteria and total bacteria in the SECC group was significantly higher than that of the CF group (live bacteria $\mathrm{t}=3.305, P=0.016$; total bacteria $\mathrm{t}=2.378, P=0.045$ ). The reduction of biofilm thickness reduced significantly in $5 \mathrm{~min}(\mathrm{t}=4.110, P=0.015)$ and in $24 \mathrm{~h}(\mathrm{t}=3.453, P=0.014)$. Long-term ( $24 \mathrm{~h})$ curcumin treatment inhibited the amount of EPS in SECC group from $(25.980 \pm 1.156) \mathrm{\mu m}^{3} / \mu^{2}$ to $(20.136 \pm 1.042) \mu \mathrm{m}^{3} / \mu \mathrm{m}^{2}$, the difference was statistically significant $(t=7.510, P<0.001)$. The gene of $g t f C, g t f D, f t f, g b p B$, fruA and srtA in the CF group and the $g t f B, g t f C, g t f D, f t f, g b p B$, sttA in SECC group were respectively reduced after 5 min curcumin treatment. After $24 \mathrm{~h}$ treatment, the $\mathrm{gtfB}, \mathrm{gtfC}, \mathrm{gtfD}, \mathrm{ftf}, \mathrm{gbpB}$, fruA and srtA in both two groups were downregulation, all the differences were statistically significant.

Conclusions: Curcumin has antibiofilm activity on clinical strains of S. mutans, especially for those isolated from SECC.

Keywords: Curcumin, Streptococcus mutans, Clinical isolates, Biofilm

\footnotetext{
*Correspondence: linhcgz@126.com; zhouy75@mail.sysu.edu.cn;

zhouy10.3@163.com

'Department of Preventive Dentistry, Hospital of Stomatology, Guanghua School of Stomatology, Sun Yat-sen University, 56 Ling Yuan Road West, Guangzhou 510055, China

Full list of author information is available at the end of the article
}

(c) The Author(s). 2020 Open Access This article is licensed under a Creative Commons Attribution 4.0 International License, which permits use, sharing, adaptation, distribution and reproduction in any medium or format, as long as you give appropriate credit to the original author(s) and the source, provide a link to the Creative Commons licence, and indicate if changes were made. The images or other third party material in this article are included in the article's Creative Commons. licence, unless indicated otherwise in a credit line to the material. If material is not included in the article's Creative Commons licence and your intended use is not permitted by statutory regulation or exceeds the permitted use, you will need to obtain permission directly from the copyright holder. To view a copy of this licence, visit http://creativecommons.org/licenses/by/4.0/ The Creative Commons Public Domain Dedication waiver (http://creativecommons.org/publicdomain/zero/1.0/) applies to the data made available in this article, unless otherwise stated in a credit line to the data. 


\section{Background}

Dental caries, especially severe early childhood caries (SECC), severely impacts the oral health of children. SECC process rapidly, lead to destruction of the primary dentition and increase the risk of new caries lesions in the permanent dentition [1]. The American Academy of Pediatric Dentistry (AAPD) defines SECC in children aged 3-5 years as: one or more cavitated, missing (due to caries) or filled smooth surface in primary maxillary anterior teeth or decayed, missing or filled surfaces greater than or equal to four (age of 3), five (age of 4) or six (age of 5) [2]. SECC is a serious public health problem and linked to a greater financial burden in China [3].

The etiology of SECC is complex and diverse. Cariogenic bacteria plays a role in the process of dental caries by forming biofilms $[4,5]$. The biofilms are highly dynamic and structured communities of microorganism that are firmly attached to teeth in a three-dimensional (3D) extracellular matrix of polymeric substances such as exopolysaccharides (EPS), proteins and nucleic acids [6, 7]. The microbial composition and structural organization of cariogenic biofilms are complex and dynamical changeable [8]. Streptococcus mutans (S. mutans) is one of the main cariogenic bacteria for caries based on its acidproducing, acid-resistant and adhesive properties [8-11]. $S$. mutans can rapidly modulate the formation of cariogenic biofilms when dietary sucrose and starch are present. Then many other organisms adhere to the biofilm and take effect $[4,12,13]$. The biofilm modulated by $S$. mutans plays a crucial role in the formation of subsequently mature and complex cariogenic biofilm. Thus, enhanced understanding of how S. mutans biofilms can be disrupted and removed from the surface of attachment could lead to improved strategies to eradicate them.

It was found that the clinical strains of $S$. mutans isolated from caries active population have stronger cariogenic ability than the isolates from caries-free (CF) people [14]. S. mutans clinical strains from different individuals have variable virulence [15]. Phenotypic traits of $S$. mutans strains would be associated with their ability to colonize tooth surface or express factors that could induce the formation of caries lesions [16]. The biological characteristic of $S$. mutans strains varied from SECC children to CF children. The strains with different biological traits would have different reaction to antibiotics.

Curcumin is a natural plant present in the Curcuma longa (turmeric) and has extensive clinical application [17]. It was used as an inhibitor of quorum sensing in bacteria [18].Previous studies have found that curcumin could decrease the biofilm activity of S. mutans UA159. It could eliminate the mature biofilm of $S$. mutans UA159 $(24 \mathrm{~h})$ by reducing the formation of EPS and change the ratio of dead and living bacteria [19].
Furthermore, we found that curcumin is more sensitive to $S$. mutans in dual-species biofilm [20]. Curcumin is a potential natural product in the antibacteria of $S$. mutans. It was reported that clinical isolates of $S$. mutans have different cariogenic properties [15]. Strains derived from SECC exhibited cariogenic traits and difficult to remove [21]. It is not clear whether curcumin has effect on the $S$. mutans isolated from SECC.

Therefore, the aim of present study is to explore the potential effect of curcumin on the biofilm of $S$. mutans strains isolated from SECC and provide evidence for the clinical application of natural compound.

\section{Results}

Different biological properties of the clinical strains of $S$. mutans

As shown in Fig. 1a, the biomass of the clinical isolates was different between two groups. The amount of biomass in the SECC group was greater than that in the CF group, and the difference was statistically significant $(\mathrm{t}=$ 4.296, $P<0.001$ ). As shown in Fig. $1 \mathrm{~b}$, the reduction of $\mathrm{pH}$ value was $1.868 \pm 0.028$ in SECC group and $1.772 \pm$ 0.225 in CF group, there was no significant difference in the acid production ability between two groups $(\mathrm{t}=1.272$, $P=0.238$ ). The aciduricity assay in Fig. 1c showed that the aciduricity of $S$. mutans in SECC group is slightly stronger than those of in CF group, but there was no significant difference between groups.

\section{The effect of curcumin on biofilm activity of S. mutans clinical strains}

As shown in Fig. 2a, there was no significant effect of curcumin on the biofilm viability of the two groups after 5 min' treatment. After long-term $(24 \mathrm{~h})$ action of curcumin in Fig. $2 b$, the biofilm activity of the SECC group was reduced to $61.865 \pm 7.108 \%$, the difference was statistically significant $(\mathrm{t}=10.731, P=0.002)$. The biofilm viability of the CF group decreased to $84.059 \pm 10.227 \%$, the difference was statistically significant $(\mathrm{t}=3.485, P=$ $0.025)$.

Figure 2c showed the net reduction of biofilm viability after $5 \mathrm{~min}$ and $24 \mathrm{~h}$ curcumin treatment. There was no significant difference between 5 min treatment. However, the biofilm viability (\%) in the SECC group decreased by $38.135 \pm 1.708 \%$, and that in the CF group decreased by $15.941 \pm 1.023 \%$ at $24 \mathrm{~h}$. The difference between the two groups was statistically significant at $24 \mathrm{~h}$. $(\mathrm{t}=3.832, P=$ 0.007).

\section{Effect of curcumin on the ration of live/dead bacteria in clinical strains of $S$. mutans}

The images of CLSM were showed in Fig. 3. Green fluorescence represented live bacteria, red fluorescence represented dead bacteria, and yellow fluorescence was 


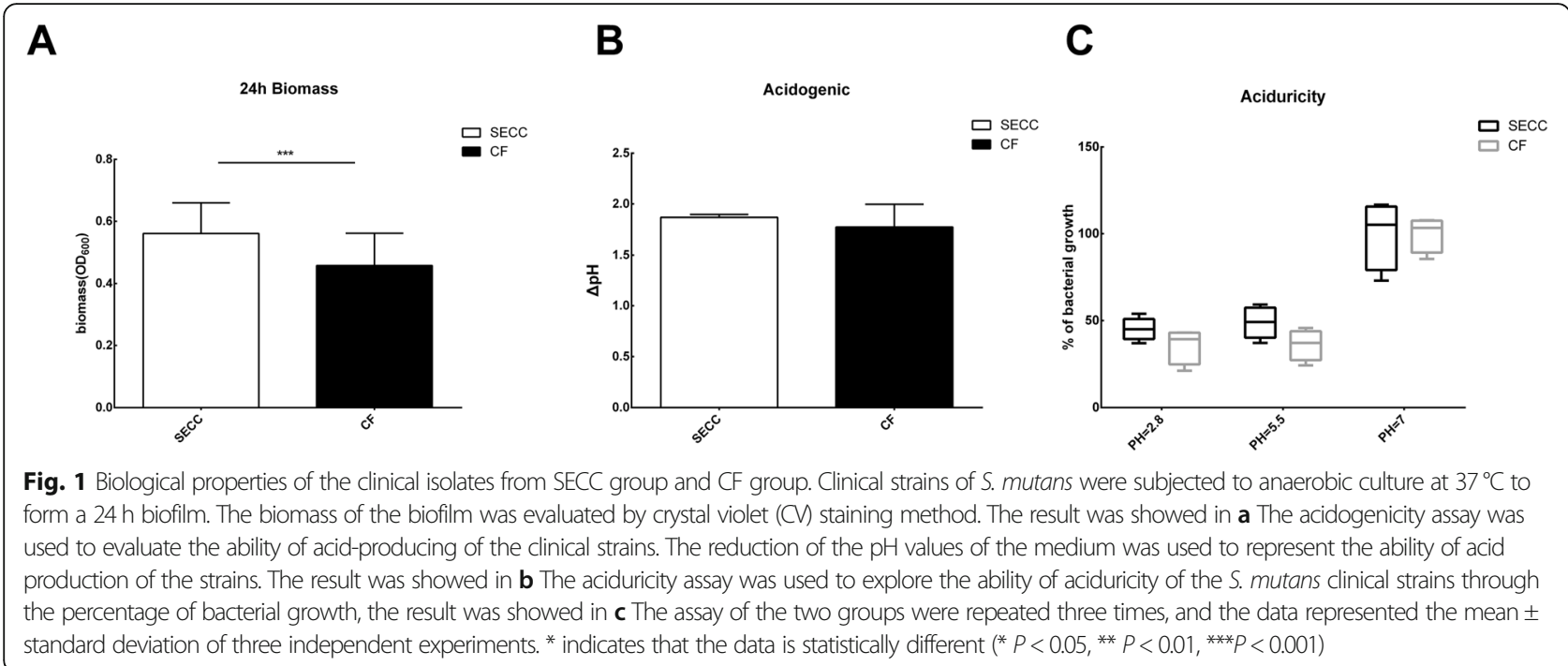

an overlap of live bacteria and dead bacteria. The image of one of the nine strains from each group was showed in Fig. 3a\&b. The green fluorescence density of the curcumin-treated group was lighter than that of the control group in both SECC group and CF group. The red fluorescence density of the curcumin-treated group was much darker in curcumin-treated group than that of the control group (Fig. 3a \&b).

The results of all the strains were combined and showed in Fig. 3c\&d. At 5 min, the amount of live bacteria in the clinical strains of $S$. mutans decreased. The change was from $(22.560 \pm 1.736) \mu \mathrm{m}^{3} / \mu \mathrm{m}^{2}$ to $(14.999 \pm$ 3.116) $\mu \mathrm{m}^{3} / \mu \mathrm{m}^{2}(\mathrm{t}=6.824, P<0.001)$ in CF group while was from $(25.460 \pm 3.579) \mu^{3} / \mu \mathrm{m}^{2}$ to $(14.228 \pm 3.237)$ $\mu \mathrm{m}^{3} / \mu \mathrm{m}^{2}(\mathrm{t}=7.726, \mathrm{P}<0.001)$ in SECC group. The total bacteria also showed the same trend. The CF group decreased from $(42.841 \pm 2.284) \mu \mathrm{m}^{3} / \mu \mathrm{m}^{2}$ to $(29.671 \pm$ 4.197) $\mu^{3} / \mu^{2}(t=7.509, P<0.001)$ and the SECC group decreased from $(48.007 \pm 1.676) \mu^{3} / \mu \mathrm{m}^{2}$ to
$(29.716 \pm 4.101) \mu \mathrm{m}^{3} / \mu \mathrm{m}^{2}(\mathrm{t}=10.304, P<0.001)$. The net reduction of live bacteria and total bacteria in the SECC group was significantly higher than that of the CF group (live bacteria $\mathrm{t}=3.017, P=0.030$; total bacteria $\mathrm{t}=2.881$, $P=0.045$ ) (Fig. 3c).

After treated with curcumin for $24 \mathrm{~h}$, the amount of live bacteria in the biofilm formed by the clinical strains of the CF group decreased from $(18.906 \pm 1.934) \mu^{3} /$ $\mu \mathrm{m}^{2}$ to $(8.860 \pm 1.192) \mu \mathrm{m}^{3} / \mu \mathrm{m}^{2}(\mathrm{t}=17.129, P<0.001)$. The amount of live bacteria in the biofilm formed by SECC group decreased from $(20.684 \pm 2.320) \mu^{3} / \mu \mathrm{m}^{2}$ to $(9.840 \pm 2.274) \mu^{3} / \mu \mathrm{m}^{2}(\mathrm{t}=12.927, \mathrm{P}<0.001)$. The amount of total bacteria also showed the descending trend. In CF group, it was decreased from (38.943 \pm 2.615) $\mu \mathrm{m}^{3} / \mu \mathrm{m}^{2}$ to $(21.005 \pm 2.381) \mu \mathrm{m}^{3} / \mu \mathrm{m}^{2}(\mathrm{t}=16.038$, $\mathrm{P}<0.001)$. In SECC group, it was decreased from $(43.716 \pm 3.812) \mu \mathrm{m}^{3} / \mu \mathrm{m}^{2}$ to $(20.839 \pm 4.016) \mu \mathrm{m}^{3} / \mu \mathrm{m}^{2}$ $(\mathrm{t}=12.008, \mathrm{P}<0.001)$. The net reduction of live bacteria and total bacteria in the SECC group was significantly

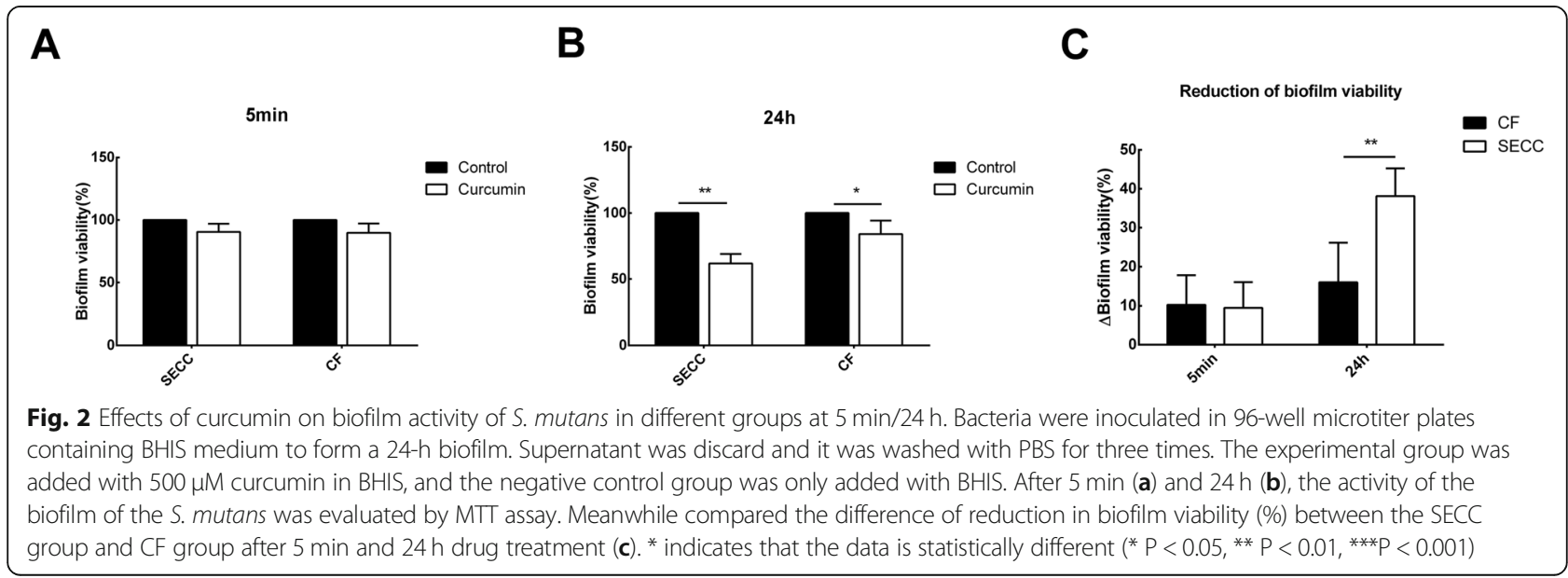



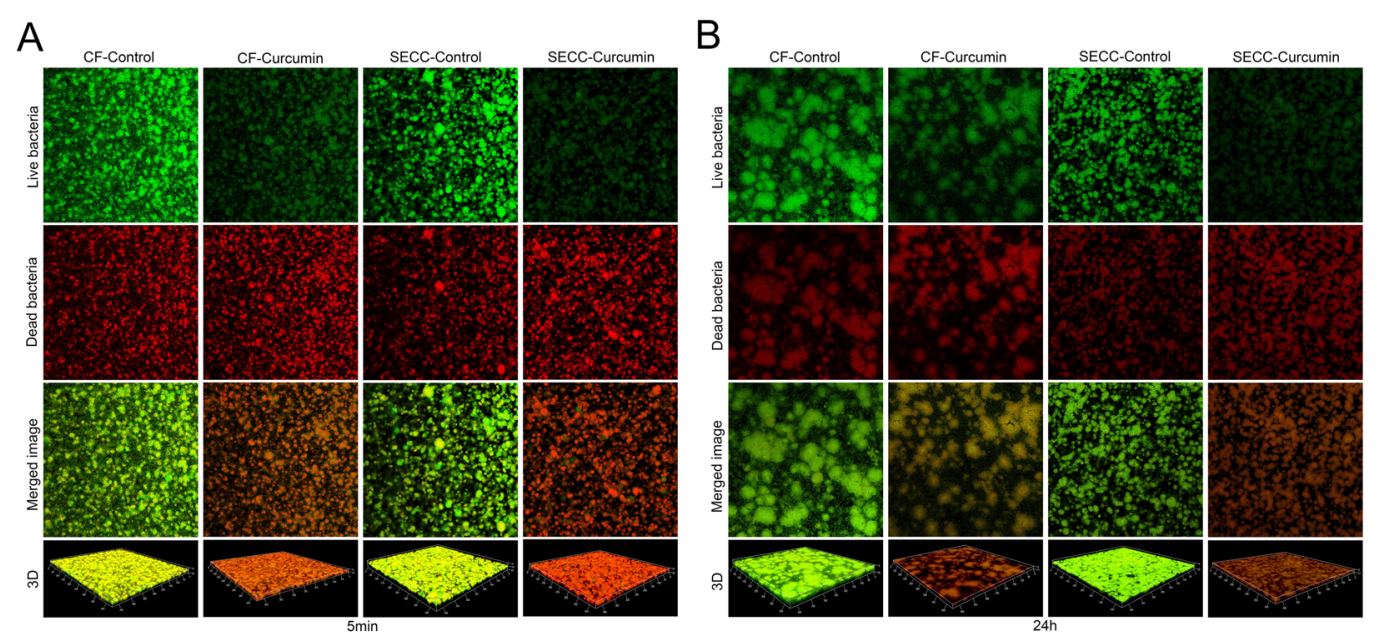

C

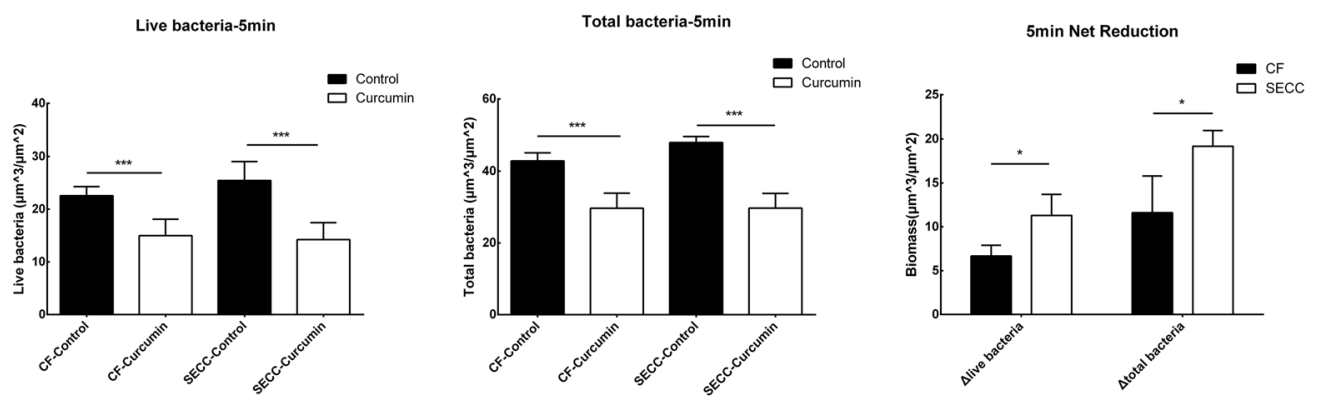

D
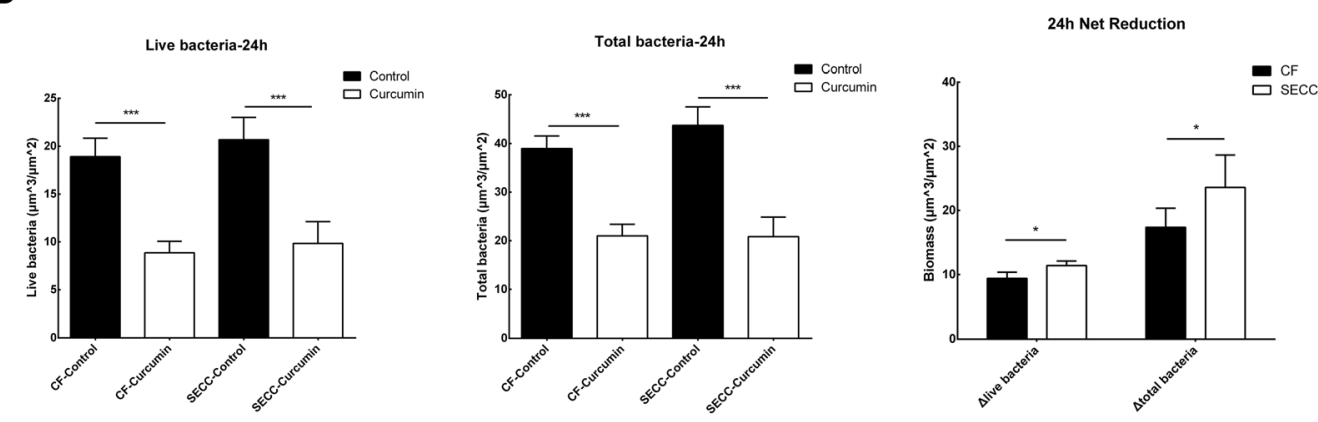

E
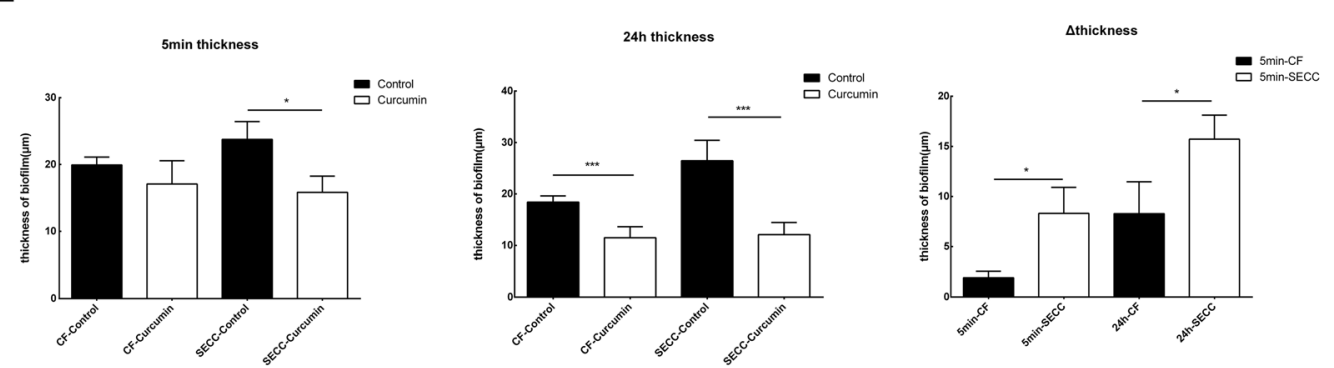

Fig. 3 (See legend on next page.) 
(See figure on previous page.)

Fig. 3 Effect of curcumin on live/dead bacteria and thickness of the biofilm of S. mutans. After mature biofilm formed by clinical strains, the biofilm was treated with $500 \mu \mathrm{M}$ curcumin for $5 \mathrm{~min}$ (a) and $24 \mathrm{~h}$ (b). The green color of image was for live bacteria, red color was for dead bacteria, merged image was for dead and live bacteria, and three-dimensional reconstruction image was also showed. $\mathbf{c}$ and $\mathbf{d}$ showed the live bacteria and total bacteria counts after the treatment of curcumin. e showed the change of the biofilm thickness after the curcumin- treated in the SECC and the CF group. The data are expressed as mean \pm standard deviation. ${ }^{*}$ indicates that the data for the different groups are statistically different $\left({ }^{*} \mathrm{P}<0.05,{ }^{* *}\right.$ $\left.P<0.01,{ }^{* * *} P<0.001\right)$

higher than that of the CF group (live bacteria $\mathrm{t}=3.305$, $P=0.016$; total bacteria $\mathrm{t}=2.378, P=0.045$ ) (Fig. $3 \mathrm{~d}$ ).

\section{The effect of curcumin on the thickness of biofilm of $S$. mutans clinical strains}

As shown in Fig. 3e, the short-term (5 min) effect of curcumin inhibited the biofilm thickness of the clinical strains from SECC group. The biofilm thickness formed by the SECC group decreased from $(23.767 \pm 2.656) \mu \mathrm{m}$ to $(15.844 \pm 2.424) \mu \mathrm{m}(\mathrm{t}=4.806, P=0.001)$. There was no difference in the strains from CF group $(t=1.903$, $P=0.084)$. But, the biofilm thickness formed by the CF group was reduced from $(18.400 \pm 1.229) \mu \mathrm{m}$ to $(11.500 \pm 2.129) \mu \mathrm{m}(\mathrm{t}=7.937, P<0.001)$ after long-term $(24 \mathrm{~h})$ effect of curcumin. SECC group decreased from $(26.450 \pm 3.984)$ to $(12.075 \pm 2.381) \mu \mathrm{m}(\mathrm{t}=5.690, P<$ 0.001). The net reduction of biofilm thickness reduced significantly in short-term effect $(\mathrm{t}=4.110, P=0.015)$ and in long-term effect $(\mathrm{t}=3.453, P=0.014)$ (Fig. 3e).

\section{Effect of curcumin on the formation of EPS of S. mutans biofilms formed by clinical strains}

In Fig. 4a and b, the green color represented the total bacteria, the red color represented EPS, and the yellow color was an overlap of EPS and bacteria. It can be seen that after treating with curcumin for $5 \mathrm{~min}$, no inhibitory effect on the biofilm EPS can be seen in both groups (Fig. 4c). However, long-term $(24 \mathrm{~h})$ curcumin treatment inhibited the amount of EPS in SECC group from $(25.980 \pm 1.156)$ $\mu \mathrm{m}^{3} / \mu \mathrm{m}^{2}$ to $(20.136 \pm 1.042) \mu \mathrm{m}^{3} / \mu \mathrm{m}^{2}$, the difference was statistically significant $(t=7.510, P<0.001)$. There was also significant inhibition on the biomass of EPS in the CF group $(\mathrm{t}=4.082, P=0.005)$ (Fig. $4 \mathrm{~d})$.

\section{Effect of curcumin on biofilm formation related genes of clinical strains of $S$. mutans}

As showed in Fig. 5, most gene expression of strains was downregulated compared to control groups. After treated by curcumin for $5 \mathrm{~min}, g t f C, g t f D, f t f, g b p B$, fruA and $s r t A$ in CF group showed a reduction, which down-regulated to 0.365-, 0.501-, 0.541-, 0.482-, 0.587-, 0.408-fold. In SECC group, the $g t f B, g t f C, g t f D, f t f, g b p B$, srtA were respectively reduced by $0.840,0.905,0.641,0.813,0.816$, 0.787 times. All the decline in both group were statistically significant (Fig. 5a).
Curcumin treatment for $24 \mathrm{~h}$ significantly inhibited the expression of genes related to the clinical strains of the SECC group and the CF group. Among them, gtfB, gtfC, $g t f D, f t f, g b p B, f r u A$ and $s r t A$ in the CF group showed a downward trend, which decreased by $0.526,0.553,0.549$, $0.486,0.507,0.482,0.530$ times, all the differences were statistically significant. In the SECC group, the $g t f B, g t f C$, $g t f D, f t f, g b p B, f r u A$, srtA down-regulated 0.530, 0.522, $0.671,0.648,0.674,0.664,0.570$ times, the differences were statistically significant (Fig. 5b).

We also conducted the gene expression of quorumsensing system of $S$. mutans biofilm (Supplemental Fig. 1). The expression of $\operatorname{comC}$ after 5-min curcumin treatment and the expression of $\operatorname{luxS}$, comD, comE, vicR after 24-h curcumin treatment are significant decreased, they down-regulated $0.392,0.380,0.332,0.335,0.334$ (Supplemental Fig. 1).

\section{Discussion}

S. mutans is the main cariogenic bacteria of dental caries. The dental biofilm formed on the tooth surface is one of its cariogenic trait. Therefore, effective removal of the $S$. mutans biofilm can prevent and control the development caries [22]. It is well known that clinical isolates of $S$. mutans isolated from different person has variable biological characteristics. The different strains showed variable ability in cariogenicity, such as dextran-forming abilities [23], glucosyltransferases (gtfs) enzymatic activity [14]. The strain of $S$. mutans isolated from cariesactive person is more capable of cariogenicity and produces more EPS [24].

In the present study, nine clinical strains from the SECC group and the CF group were respectively selected and evaluated. Though the acidogenicity and aciduricity showed no significant difference between the two groups, more biomass was formed by strains from SECC group than those from CF group. Different biomass formation showed the cariogenic ability between the two groups of clinical strains were mainly biofilms-mediated. S. mutans strains from SECC group had more cariogenic ability probably based on the formation of biofilm. This is consist with previous reports [23] [24].

This study found that with the treatment of curcumin for $24 \mathrm{~h}$, the biofilm viability was inhibited both in the SECC and CF group. The results showed that curcumin has an inhibitory effect on the biofilm viability of clinical 


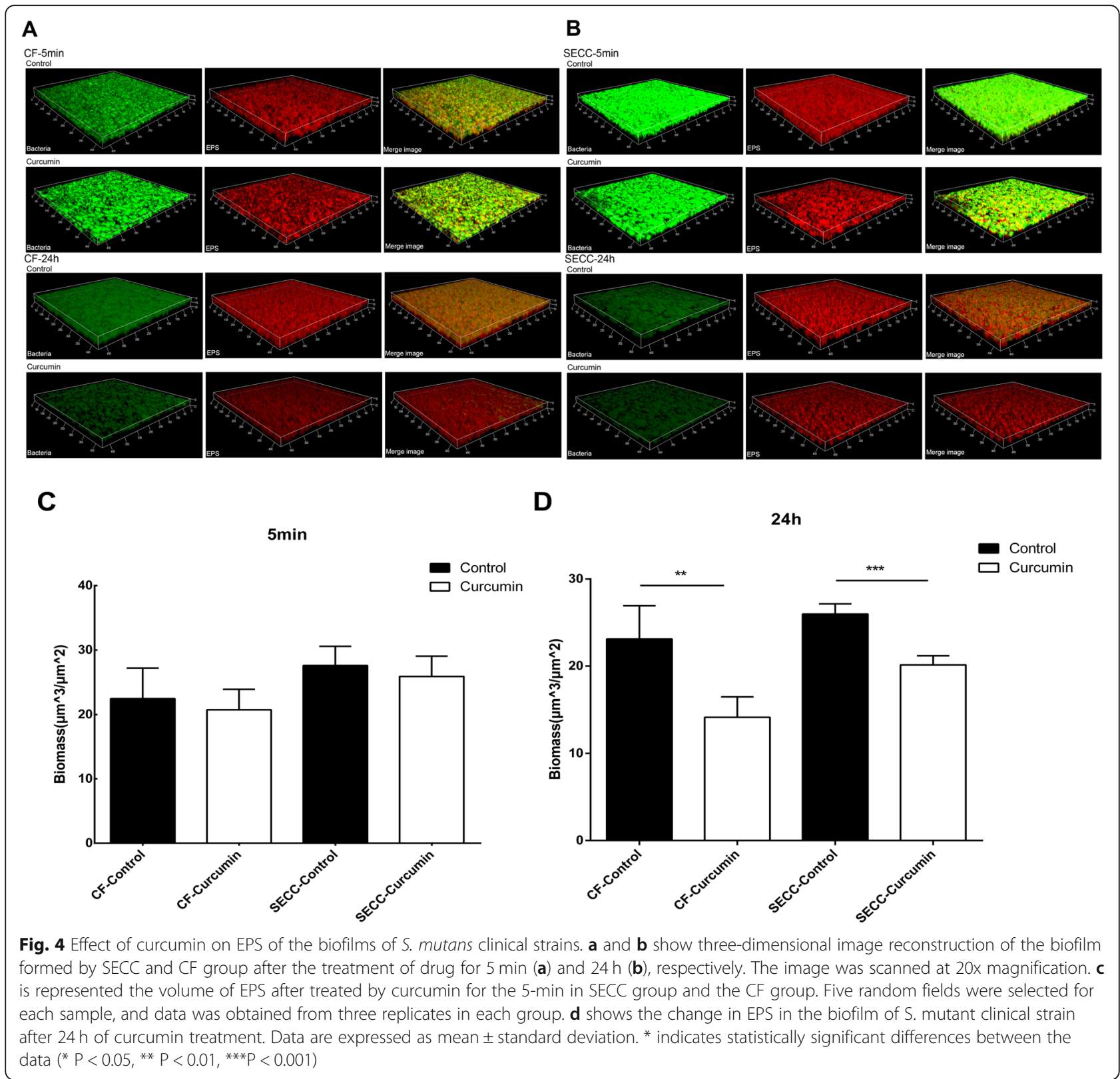

strains of $S$. mutans. It indicated that the long-term effect of curcumin is stronger than the short-term effect.

Then, we proceeded to explore the effect of curcumin on the live bacteria, total bacteria and thickness of biofilm by CLSM. The results revealed that curcumin was not only decreased the amount of live and total bacteria of biofilm, but also reduced the thickness of biofilm. One of the interesting finding was that more reduction of live bacteria and total bacteria was discovered on strains from SECC. The inhibitory effect on SECC group was stronger than that in CF group, indicating that curcumin may be specific on the inhibition of high biofilm-forming strains. The clinical strains of $S$. mutans from SECC formed more biomass compared to caries-free strains. Curcumin inhibited biofilm formation of $S$. mutans through disrupt of exoploysaccharides [25]. More exoploysaccharides were disrupted by curcumin on SECC group and thus inhibited biofilm formation of SECC group.

Extracellular matrices include extracellular polysaccharide (EPS), lipoteichoic acid, and nucleic acids [13]. Extracellular polysaccharide (EPS) are the main constituents of the matrix in cariogenic biofilms and are recognized as essential virulence factors associated 


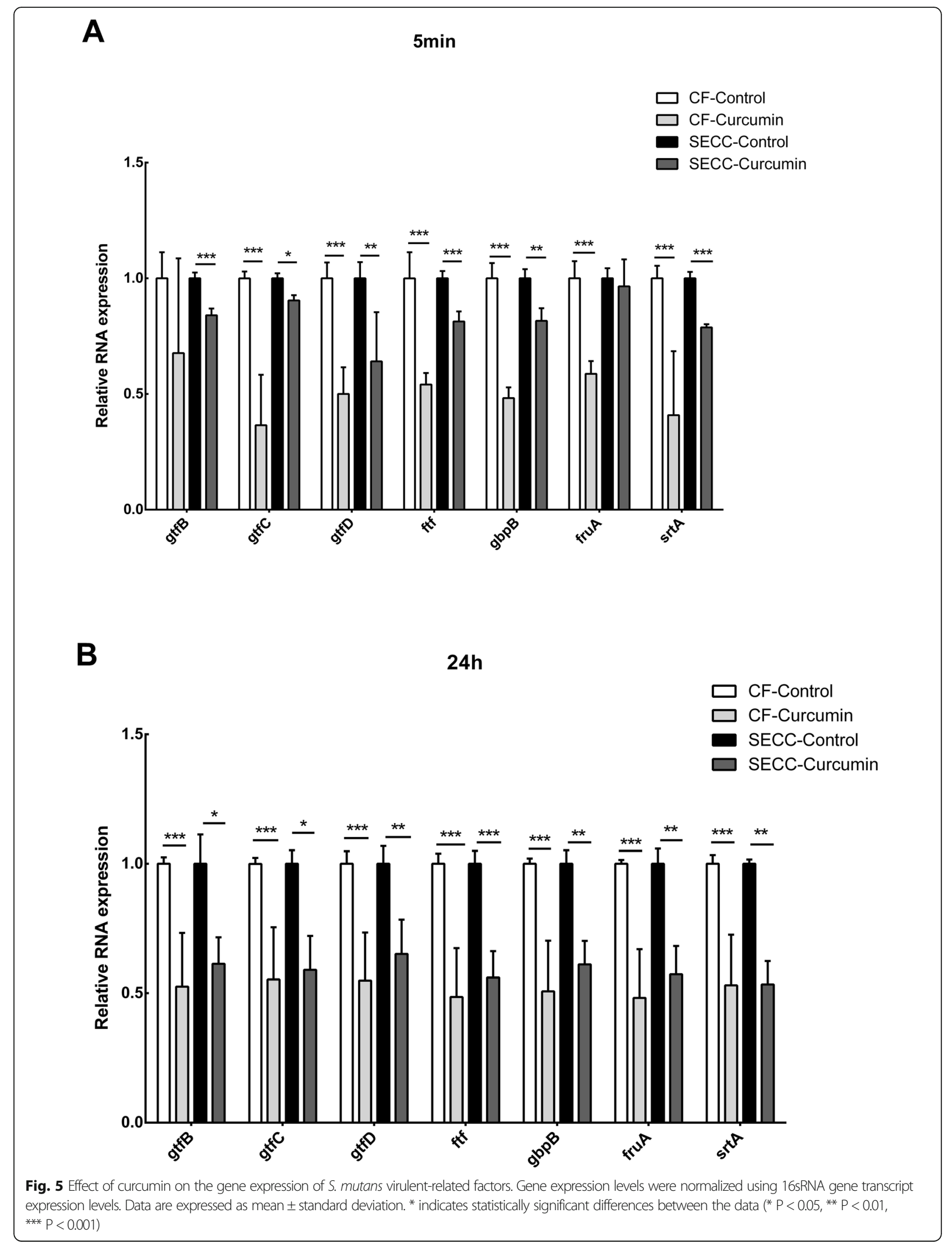


with dental caries. The lipoteichoic acid and nucleic acids can contribute with matrix development by modulating the assembly, structural organization and functional properties of the matrix during cariogenic biofilm formation [13]. The EPS account for about $40 \%$ of the dry weight of mature biofilms, and the decrease of biofilm content may be related to the decrease of EPS in the whole biofilm matrix [26]. The results showed that curcumin significant reduced the amounts of EPS in biofilm at $24 \mathrm{~h}$ but not at $5 \mathrm{~min}$. The EPS of clinical strains was not sensitive to curcumin in a short term which coincide with the effect on biofilm viability.

The decrease of biofilm thickness probably because the components of biofilm reduced. The amount of bacteria and of extracellular matrix secreted by bacteria inhibited by curcumin. The inhibition of bacteria and EPS in SECC group was more efficient, the reduction of thickness in SECC was more obvious. The reduction of biofilm thickness would cause the deformation of the three-dimensional structures of biofilm, which could take an effect on cariogenic of $S$. mutans.

In our study, the cariogenic ability between the two groups of clinical strains were mainly biofilms-mediated. The process of biofilm formation by $S$. mutans via two independent mechanisms: sucrose-dependent and sucroseindependent [27]. The sucrose-dependent mechanism of plaque formation is based on glucosyltransferases (GTFB, $-C$, and-D) produced by $S$. mutans in combination with glucan-binding proteins (GBPs) [28]. The sucroseindependent mechanism is not relevant in the virulence of S. mutans but in adhesion [28]. Therefore, we examined the effect of curcumin on these two pathogenic mechanism-related genes of $S$. mutans.

As the results showed, we found that curcumin may inhibit the biofilm activity of clinical strains of $S$. mutans through inhibited the expression of genes involved in biofilm formation. The formation of EPS of S. mutans mainly included glucosyltransferases and fructosyltransferase [29]. The glucosyltransferase (gtfs) is an essential enzyme for bacteria to utilize sucrose and form glucan, which plays an important role in the formation of biofilm and the development of dental caries [30]. Gtfs encoded by the $g t f B, g t f D$, and $g t f C$ gene which synthesized water-insoluble glucan, soluble glucan, and the mixture [31-33]. Fructosyltransferases are primarily enzymes that convert sucrose into extracellular fructose homopolymers encoded by the $f t f$ gene [34]. The expression of above genes expression degraded both in SECC and CF group.

In addition, bacteria aggregation is also an important condition for the formation of EPS, which is mediated by glucan binding protein (Gbp), which promotes the formation of plaque [35]. Previous research shows that the absence or mutation of the gene encoding GbpB results in a change of cell shape and a slowing down of its growth. This disables the appropriate development of biofilm, which becomes a product of non-regular cell clusters surrounded by a matrix of unusual structure [36]. The qPCR experiment found that curcumin inhibited the formation of EPS-related genes of the CF and SECC group clinical $S$. mutans biofilm, and it was inconsistent with the changes of EPS in the CF group. The expression of $S$. mutans associated virulence genes is a complex regulatory network. This research mainly detects changes in the expression of genes involved in the formation of EPS. The results of the decreased expression of these genes were consistent with the results of the biological characteristics of the SECC group, but were not confirmed in the CF group, indicating that curcumin may be different for CF and SECC group $S$. mutans clinical strains. The results of quorum-sensing system showed that Curcumin has little inhibitory effect on the genes of SECC and CF group after $5 \mathrm{~min}$, while it can effectively inhibit related genes in SECC group after $24 \mathrm{~h}$. However, curcumin's inhibitory effect on the quorum-sensing system is not as obvious as that of the glucosyltransferases at short term time point. It proved that other gene regulatory systems may also be involved in mediating the effect of curcumin. The complex regulatory mechanism leads to differences in its inhibitory effects, and further research is needed. All the above experiment results indicated that after the effect of curcumin, the gene expression of glucosyltransferases and the amount of bacteria were reduced, which further decreased of EPS production and lessened of biofilm thickness. Our experiment results showed that curcumin could inhibit biofilm formation in SECC group through inhibit EPS production. Moreover, the longer curcumin acts, the more obvious its inhibitory effect. The results suggested that curcumin can effectively inhibit the cariogenicity of $S$. mutans biofilm. The stronger long-term effect of curcumin reminds us that in subsequent clinical applications, in addition to applying curcumin to short-term antibacterial products such as mouthwash, it can also be added to dental materials with slow release effects.

As previous reported showed, the eDNA and LTA also play a crucial role in the formation of $S$. mutans biofilm [13].We would continue to explore the relevant mechanism. Furthermore, how gene changes work through protein regulation. How curcumin inhibits the reduction of the number of $S$. mutans bacteria, whether there are other pathways that curcumin inhibit the cariogenic of $S$. mutans biofilm, still need to be further explored. 
In summary, curcumin has antibiofilm activity on clinical strains of $S$. mutans, especially for those isolated from SECC.

\section{Conclusion}

Curcumin has variable effect on the different clinical isolates. It has more effective long-term anti-biofilm activity in SECC clinical strains than CF clinical strains.

\section{Methods}

\section{Clinical strains}

The clinical isolates of $S$. mutans were derived from a previous study [37]. S. mutans strains were isolated from children without caries (CF group) and children with a DMFT index of $\geq 6$ (SECC group). A subset of nine $S$. mutans clinical strains were randomly selected from the SECC and CF group separately. In total, eighteen isolates of $S$. mutans were used in the next step.

\section{Growth condition of clinical strains}

The clinical isolates were inoculated on the brain heart infusion broth (BHI) medium and incubated in $37^{\circ} \mathrm{C}$, $85 \% \mathrm{~N}_{2}, 5 \% \mathrm{CO}_{2}, 10 \% \mathrm{H}_{2}$ anaerobic culture, observed after $24 \mathrm{~h}$. After the bacterial morphology was confirmed to be pure culture, the single colony was collected and incubated into the BHI culture solution. After overnight culture, the bacterial solution was normalized to $\mathrm{OD} \approx$ $0.5\left(10^{8}\right.$ colony forming units per milliliter $\left.(\mathrm{CFU} / \mathrm{ml})\right)$, and diluted 10 -fold $\left(10^{7} \mathrm{CFU} / \mathrm{ml}\right)$ for the experiment.

\section{The biological characters of the clinical strains of $S$. mutans}

\section{Biomass of the clinical strains of S. mutans}

Crystal violet staining were used to evaluate the biomass of clinical strains [38, 39]. Clinical strains from two groups were cultured in 96-well flat plates for $24 \mathrm{~h}$ to form biofilm. The medium is BHI with $1 \%$ sucrose $(1 \%$ BHIS). Then, the contents of the microplate were removed and the wells were washed with PBS, fixed with 95\% methanol, washed again and stained with $0.1 \%$ (wt/ vol) crystal violet solution for $15 \mathrm{~min}$ at room temperature. Subsequently, the microplates were vigorously tapped on napkins to remove any excess liquid and air-dried. The remaining CV was dissolved in $100 \mu \mathrm{l}$ absolute ethanol for $15 \mathrm{~min}$ at room temperature, and finally, $75 \mu \mathrm{l}$ from each sample was transferred to a new 96-well plate, and the extract was read at $600 \mathrm{~nm}$ in a spectrophotometer $[19,38,39]$. The experiments were repeated for three times independently.

\section{Acidogenicity of the clinical strains of S. mutans}

The bacterial suspensions of the SECC group and the CF group were sequentially inoculated into the BHI medium (1:100). The $\mathrm{pH}$ value of the medium was measured before the growth of the strains by the $\mathrm{pH}$ meter (METTLER TOLEDO, Switzerland) and was set as $\mathrm{pH}$. Cultured under anaerobic conditions for $48 \mathrm{~h}$ at $37^{\circ} \mathrm{C}$, the culture was centrifuged at $4{ }^{\circ} \mathrm{C}, 3000 \mathrm{r} / \mathrm{min}$ for $15 \mathrm{~min}$ and the supernatant medium was taken. The $\mathrm{pH}$ value of the supernatant was measured and was set as $\mathrm{pH} 1$. The reduction of the $\mathrm{pH}$ values of the medium was used to represent the ability of acid production of the strains. The calculation was $\Delta \mathrm{pH}=\mathrm{pH} 0-\mathrm{pH} 1$ [40]. Each sample was taken in triplicate. The acidogenicity of two groups was assessed.

\section{Aciduricity of the clinical strains of S. mutans}

The aciduricity was acid tolerance ability of clinical strains under acidic environment. The clinical strains of S. mutans was resuscitated and cultured overnight. The bacterial solution was normalized to $\mathrm{OD} \approx 0.5\left(10^{8} \mathrm{col}-\right.$ ony forming units per milliliter $(\mathrm{CFU} / \mathrm{ml}))$, and diluted 10 -fold $\left(10^{7} \mathrm{CFU} / \mathrm{ml}\right)$ for the experiment. Then, the medium was changed for fresh acidic BHI medium. The $\mathrm{pH}$ value of fresh $\mathrm{BHI}$ medium was set at $\mathrm{pH}=2.8,5.5$ and 7.0 for acid pressure stimulation $(50 \mathrm{mM} \mathrm{KCl}$ and 1 $\mathrm{mM} \mathrm{MgCl2,} 0.1 \mathrm{M}$ glycine buffer). The mixture was continuously agitated at room temperature. The medium at 0 (T0) and $60 \mathrm{~min}$ (T60) was collected and spread with BHI plates. The number of bacteria CFU was calculated after anaerobic incubation of the BHI plate for $48 \mathrm{~h}$ as detailed previously $[21,41,42]$. Bacteria viability at each time point was expressed as the percentage of bacterial growth in relation to $\mathrm{T}_{0}(100 \%)$. Analyses were performed in triplicate.

The effect of curcumin on the clinical strains of S. mutans Biofilm metabolism assessment by MTT assay

The $500 \mu \mathrm{M}$ concentration of curcumin was prepared from the powder of curcumin (Sigma, USA), which stocked in dimethyl sulfoxide (DMSO) with $250 \mathrm{mM}$ concentration and was diluted in BHI. The bacterial strains of the SECC group and the CF group were added to a 96-well flat plate, cultured at $37^{\circ} \mathrm{C}, 5 \% \mathrm{CO}_{2}$ incubator in BHIS to form $24 \mathrm{~h}$ biofilm. The biofilm was rinsed twice with sterile physiological saline (PBS).

The fresh medium contained $500 \mu \mathrm{M}$ curcumin was used in the experiment. The negative control was the curcumin-free medium with bacterial solution and the blank control was the curcumin medium without bacterial solution. Both groups have their own negative control wells and blank control wells. Then, after incubated for 5 min and $24 \mathrm{~h}$ at $37^{\circ} \mathrm{C}, 5 \% \mathrm{CO}_{2}$ incubator, thiazolyl bromide at a final concentration of $0.5 \mathrm{mg} / \mathrm{ml}$ was added and incubated in the dark at $37^{\circ} \mathrm{C}, 5 \% \mathrm{CO}_{2}$ incubator for $3 \mathrm{~h}$. The supernatant of the plates was discard and rinsed twice with PBS. $100 \mu \mathrm{l}$ absolute DMSO was added into wells and $75 \mu \mathrm{l}$ from each wells were transferred to a new 96- 
well plate. The extract was read at $570 \mathrm{~nm}$ in a spectrophotometer. The biofilm viability $(\%)=($ experimental absorbance value-blank absorbance value) / (negative control absorbance value-blank absorbance value) $\times 100 \%$.

\section{Analysis the ratio of live and total bacteria and the thickness of biofilm by CLSM}

Confocal Laser scanning microscopy (CLSM) was used to detect the ratio of dead and live bacteria and the biofilm thickness after curcumin treatment in clinical strains of $S$. mutans. Formed biofilm in confocal culture dish was incubated with curcumin for $5 \mathrm{~min}$ and $24 \mathrm{~h}$. After washed with PBS, the dye stained with live and dead bacteria was added into plates and incubated at room temperature for $15 \mathrm{~min}$. The dye was from L-7012 LIVE/DEAD ${ }^{\circ}$ BacLight $^{\text {tm }}$ Bacterial Viability Kits (Molecular Probes, Eugene, OR, USA). Then, biofilm washed with PBS for three times, and captured using a laser scanning microscope to capture biofilm images through ImageJ software (Bitplane, Switzerland) provides a threedimensional image of the biofilm. Biomass $\left(\mathrm{mm}^{3} / \mathrm{mm}^{2}\right)$ for each channel was calculated by COMSTAT, and the proportion of dead bacteria and biofilm thickness can be calculated.

\section{Analysis extracellular polysaccharides of clinical strains of $S$. mutans}

The sample was added to the confocal culture dish, and the concentration of $1 \mu \mathrm{M}$ Alexa Fluor ${ }^{\circ}$ 647-labeled dextran conjugate red fluorescent dye was added. The biofilm was formed in the $5 \% \mathrm{CO}_{2}$ incubator for $24 \mathrm{~h}$ at $37^{\circ} \mathrm{C}$. After washing the biofilm with PBS, biofilm was stained with green fluorescent SYTO9 and incubated at room temperature for $15 \mathrm{~min}$; using a CLSM to capture the organism Membrane images, three-dimensional images of biofilms were provided by Image 7.0 software. The biofilm biomass $\left(\mathrm{mm}^{3} / \mathrm{mm}^{2}\right)$ of each channel was calculated by COMSTAT, and the amount of extracellular polysaccharides (EPS) was calculated.

\section{Analysis gene expression by real-time $P C R$}

The expression of $S$. mutans-associated virulence factors was evaluated by real-time quantitative PCR. Total RNA was extracted by ultrasonic crushing and using the RNeasy Mini Kit (QIAGEN, Valencia, CA, USA), determined purity and RNA concentration by NanoDrop 2000 spectrophotometer (Thermo Fisher Scientific, Pittsburgh, PA, USA), reverse transcription and realtime quantitative PCR were performed, and the change in fold expression of the relevant gene was calculated using $2^{-\Delta \Delta \mathrm{CT}}[19]$.

\section{Statistical analysis}

Each experiment was repeated three times independently. Statistical analysis was performed using SPSS 17.0. The data were assessed to determine whether they were normally distributed. The t-test was used to test the difference between the control- and the experimental-group. The difference was statistically significant at $P<0.05$.

\section{Supplementary information}

Supplementary information accompanies this paper at https://doi.org/10. 1186/s12866-020-01975-5.

Additional file 1: Fig. 1. Effect of curcumin on the gene expression of quorum-sensing system. ${ }^{*}$ indicates statistically significant differences between the data $\left({ }^{*} P<0.05,{ }^{* *} P<0.01,{ }^{* * *} P<0.001\right)$.

\section{Abbreviations}

S. mutans: Streptococcus mutans; CF: Caries-free; SECC: Severe early childhood caries; AAPD: The American Academy of Pediatric Dentistry; DMFT: Decayed, missing and filled teeth; CFU: Colony forming units; BHI: Brain heart infusion broth; CV: Crystal violet; MTT: 3-(4,5-dimethyl-2-thiazolyl)-2,5-diphenyl-2-Htetrazolium bromide; DMSO: Dimethyl sulfoxide; PBS: Physiological saline; CLSM: Confocal Laser scanning microscopy; PCR: Polymerase Chain Reaction; EPS: Extracellular polysaccharide; gtfs: Glucosyltransferase; gbp: Glucan binding protein; fru: Fructosyltransferase

\section{Acknowledgments}

Not applicable.

Authors' contributions

$B L$ and $Y Z$ designed the experiments. BL and TP conducted the experiments, $B L$ drafted the manuscript. $H L$ and $Y Z$ revised the manuscript. All authors read and approved the manuscript.

\section{Funding}

This work was supported by the Guangdong Financial Fund for High-Caliber Hospital Construction. Study grant NO 174-2018-XMZC-0001-03-0125/-03, funding body had no role in design of the study, analysis, and interpretation of data.

\section{Availability of data and materials}

Yes, available from corresponding author on request.

\section{Ethics approval and consent to participate}

This study obtained ethical approval from an ethics committee of Sun Yatsen University (Number is ERC- [2012]-13). Written informed consent was obtained from a parent or guardian of all participants in this study.

Consent for publication

Not applicable.

Competing interests

We declare that we have no competing interests.

\section{Author details}

${ }^{1}$ Department of Preventive Dentistry, Hospital of Stomatology, Guanghua School of Stomatology, Sun Yat-sen University, 56 Ling Yuan Road West, Guangzhou 510055, China. ${ }^{2}$ Guangdong Provincial Key Laboratory of Stomatology, Sun Yat-Sen University, Guangzhou, China.

Received: 22 May 2020 Accepted: 10 September 2020

Published online: 16 September 2020

\section{References}

1. Ng MW, Chase I. Early childhood caries: risk-based disease prevention and management. Dent Clin N Am. 2013;57(1):1-16. 
2. American Academy on Pediatric D, American Academy of P. Policy on early childhood caries (ECC): classifications, consequences, and preventive strategies. Pediatr Dent. 2008;30(7 Suppl):40-3.

3. Xie YY, Cheng ML, Xu MR, Si Y, Xu T. Cost-effectiveness analysis of comprehensive Oral health Care for Severe Early Childhood Caries in urban Beijing, China. Chin J Dent Res. 2019;22(1):45-50.

4. Paes Leme AF, Koo H, Bellato CM, Bedi G, Cury JA. The role of sucrose in cariogenic dental biofilm formation--new insight. J Dent Res. 2006;85(10): 878-87.

5. Sheiham A, James WP. Diet and dental caries: the pivotal role of free sugars reemphasized. J Dent Res. 2015;94(10):1341-7.

6. Branda SS, Vik S, Friedman L, Kolter R. Biofilms: the matrix revisited. Trends Microbiol. 2005:13(1):20-6.

7. Flemming HC, Wingender J. The biofilm matrix. Nat Rev Microbiol. 2010;8(9): 623-33.

8. Marsh PD. Are dental diseases examples of ecological catastrophes? Microbiology. 2003;149(Pt 2):279-94.

9. Loesche WJ. Role of Streptococcus mutans in human dental decay. Microbiol Rev. 1986;50(4):353-80.

10. Inquimbert C, Bourgeois D, Giraudeau N, Tramini P, Viennot S, Dussart C, et al. Microbiota of interdental space of adolescents according to risk of caries: a cross-sectional study protocol. Contemp Clin Trials Commun. 2019; 16:100444.

11. Young DA, Featherstone JD. Caries management by risk assessment. Community Dent Oral Epidemiol. 2013;41(1):e53-63.

12. Ribeiro CC, Tabchoury CP, Del Bel Cury AA, Tenuta LM, Rosalen PL, Cury JA. Effect of starch on the cariogenic potential of sucrose. Br J Nutr. 2005;94(1): 44-50.

13. Klein MI, Hwang G, Santos PH, Campanella OH, Koo H. Streptococcus mutans-derived extracellular matrix in cariogenic oral biofilms. Front Cell Infect Microbiol. 2015;5:10.

14. Napimoga MH, Kamiya RU, Rosa RT, Rosa EA, Hofling JF, Mattos-Graner R, et al. Genotypic diversity and virulence traits of Streptococcus mutans in caries-free and caries-active individuals. J Med Microbiol. 2004;53(Pt 7):697703.

15. Lapirattanakul J, Takashima $Y$, Tantivitayakul $P$, Maudcheingka T, Leelataweewud P, Nakano K, et al. Cariogenic properties of Streptococcus mutans clinical isolates with sortase defects. Arch Oral Biol. 2017:81:7-14.

16. Lembo FL, Longo PL, Ota-Tsuzuki C, Rodrigues CR, Mayer MP. Genotypic and phenotypic analysis of Streptococcus mutans from different oral cavity sites of caries-free and caries-active children. Oral Microbiol Immunol. 2007; 22(5):313-9

17. Salehi B, Stojanovic-Radic Z, Matejic J, Sharifi-Rad M, Anil Kumar NV, Martins $\mathrm{N}$, et al. The therapeutic potential of curcumin: a review of clinical trials. Eur J Med Chem. 2019;163:527-45.

18. Deryabin D, Galadzhieva A, Kosyan D, Duskaev G. Plant-Derived Inhibitors of AHL-Mediated Quorum Sensing in Bacteria: Modes of Action. Int J Mol Sci. 2019;20(22):5588.

19. Li BC, Li XL, Lin HC, Zhou Y. Curcumin as a Promising Antibacterial Agent: Effects on Metabolism and Biofilm Formation in S. mutans. Biomed Res Int 2018;2018:4508709.

20. Li X, Yin L, Ramage G, Li B, Tao Y, Zhi Q, et al. Assessing the impact of curcumin on dual-species biofilms formed by Streptococcus mutans and Candida albicans. Microbiologyopen. 2019;8(12):e937.

21. Valdez RMA, Duque C, Caiaffa KS, Dos Santos VR, Loesch MLA, Colombo NH, et al. Genotypic diversity and phenotypic traits of Streptococcus mutans isolates and their relation to severity of early childhood caries. BMC Oral Health. 2017;17(1):115.

22. Kunze B, Reck M, Dotsch A, Lemme A, Schummer D, Irschik H, et al. Damage of Streptococcus mutans biofilms by carolacton, a secondary metabolite from the myxobacterium Sorangium cellulosum. BMC Microbiol. 2010;10:199.

23. Napimoga MH, Hofling JF, Klein MI, Kamiya RU, Goncalves RB. Tansmission, diversity and virulence factors of Sreptococcus mutans genotypes. J Oral Sci. 2005;47(2):59-64

24. Khoo G, Zhan L, Hoover C, Featherstone JD. Cariogenic virulence characteristics of mutans streptococci isolated from caries-active and cariesfree adults. J Calif Dent Assoc. 2005:33(12):973-80.

25. Bottner A, He RY, Sarbu A, Nainar SMH, Dufour D, Gong SG, et al. Streptococcus mutans isolated from children with severe-early childhood caries form higher levels of persisters. Arch Oral Biol. 2020;110:104601.
26. Pandit S, Jung JE, Choi HM, Jeon JG. Effect of brief periodic fluoride treatments on the virulence and composition of a cariogenic biofilm. Biofouling. 2018;34(1):53-61.

27. Wen ZT, Yates D, Ahn SJ, Burne RA. Biofilm formation and virulence expression by Streptococcus mutans are altered when grown in dualspecies model. BMC Microbiol. 2010;10:111.

28. Krzysciak W, Jurczak A, Koscielniak D, Bystrowska B, Skalniak A. The virulence of Streptococcus mutans and the ability to form biofilms. Eur J Clin Microbiol Infect Dis. 2014;33(4):499-515.

29. Senadheera MD, Guggenheim B, Spatafora GA, Huang YC, Choi J, Hung DC, et al. A VicRK signal transduction system in Streptococcus mutans affects gtfBCD, gbpB, and ftf expression, biofilm formation, and genetic competence development. J Bacteriol. 2005;187(12):4064-76.

30. Liu S, Qiu W, Zhang K, Zhou X, Ren B, He J, et al. Nicotine enhances interspecies relationship between Streptococcus mutans and Candida albicans. Biomed Res Int. 2017;2017:7953920.

31. Hamada S, Slade HD. Biology, immunology, and cariogenicity of Streptococcus mutans. Microbiol Rev. 1980;44(2):331-84.

32. Nakano YJ, Kuramitsu HK. Mechanism of Streptococcus mutans glucosyltransferases: hybrid-enzyme analysis. J Bacteriol. 1992;174(17):5639-46.

33. Bowen $\mathrm{WH}, \mathrm{KoO} \mathrm{H}$. Biology of Streptococcus mutans-derived glucosyltransferases: role in extracellular matrix formation of cariogenic biofilms. Caries Res. 2011;45(1):69-86.

34. Burne RA, Penders JE. Differential localization of the Streptococcus mutans GS5 fructan hydrolase enzyme. FruA FEMS Microbiol Lett. 1994;121(2):243-9.

35. He ZY, Wang $Q, H u$ YJ, Liang JP, Jiang YT, Ma R, et al. Use of the quorum sensing inhibitor furanone C-30 to interfere with biofilm formation by Streptococcus mutans and its luxS mutant strain. Int J Antimicrob Ag. 2012; 40(1):30-5.

36. Duque C, Stipp RN, Wang B, Smith DJ, Hofling JF, Kuramitsu HK, et al. Downregulation of GbpB, a component of the VicRK regulon, affects biofilm formation and cell surface characteristics of Streptococcus mutans. Infect Immun. 2011;79(2):786-96

37. Yu LX, Tao Y, Qiu RM, Zhou Y, Zhi QH, Lin HC. Genetic polymorphisms of the sortase A gene and social-behavioural factors associated with caries in children: a case-control study. BMC Oral Health. 2015;15:54.

38. Bedran TB, Grignon L, Spolidorio DP, Grenier D. Subinhibitory concentrations of triclosan promote Streptococcus mutans biofilm formation and adherence to oral epithelial cells. PLoS One. 2014;9(2):e89059.

39. He Z, Huang Z, Jiang W, Zhou W. Antimicrobial activity of Cinnamaldehyde on Streptococcus mutans biofilms. Front Microbiol. 2019;10:2241.

40. Ito $Y$, Ito $T$, Yamashiro $K$, Mineshiba F, Hirai K, Omori $K$, et al. Antimicrobial and antibiofilm effects of abietic acid on cariogenic Streptococcus mutans. Odontology. 2020;108(1):57-65.

41. Turner ME, Huynh K, Carney OV, Gross D, Carroll RK, Ahn SJ, et al. Genomic instability of TnSMU2 contributes to Streptococcus mutans biofilm development and competence in a cidB mutant. Microbiologyopen. 2019; 8(12):e934.

42. Guo LH, McLean JS, Lux R, He XS, Shi WY. The well-coordinated linkage between acidogenicity and aciduricity via insoluble glucans on the surface of Streptococcus mutans. Sci Rep-Uk. 2015;5:18015.

\section{Publisher's Note}

Springer Nature remains neutral with regard to jurisdictional claims in published maps and institutional affiliations.

\section{Ready to submit your research? Choose BMC and benefit from:}

- fast, convenient online submission

- thorough peer review by experienced researchers in your field

- rapid publication on acceptance

- support for research data, including large and complex data types

- gold Open Access which fosters wider collaboration and increased citations

- maximum visibility for your research: over $100 \mathrm{M}$ website views per year

At $\mathrm{BMC}$, research is always in progress.

Learn more biomedcentral.com/submission 